UDC $339.56+327$

DOI: https://doi.org/10.32840/1814-1161/2019-5-4

Yangbin Mao

Prof., Dr.

Shanghai University, School of Economics

Bakhantsova Svetlana

Economic Faculty Master Student

Shanghai University School of Economics

Янбін Мао

Профресор, доктор,

Шанхайский Університет

Баханцова C.B.

студентка факультету економіки, спеціальність «Міжнародна торгівля»,

Шанхайский Університет

\title{
INTERNATIONAL RELATIONS AND INTERNATIONAL TRADE OF CHINA WITH EU COUNTRIES
}

\author{
МІЖНАРОДНІ ВІДНОСИНИ І МІЖНАРОДНА ТОРГІВЛЯ \\ КИТАЮ 3 КРАЇНАМИ ЄС
}

This article, as an example of the impact of globalization on the system of modern international relations of states, discusses the development trends of international relations between the People's Republic of China and its main partners, which occupy leading positions on the political map of the world, exerting a strong influence on the course of international events and processes in conditions of global changes. Simultaneously, this process encounters difficulties and contradictions in its way. The article highlights China's foreign economic relations with the leading countries of the world. The trade, economic and investment cooperation of China with the EU countries is analysed. The relevance of the study is determined by the fact that China and the European Union are the leading players in world politics. Therefore, the study of the foreign policy of the PRC towards the EU is of great scientific and practical importance. The research topic is justified by the emergence of new factors and conditions affecting the development of Sino-European economic cooperation and, in this regard, the identification of the most promising areas for such cooperation. The basis of China's international relations model is the harmonization of relations with the countries of the world.

Keywords: globalization, international relations, international trade, foreign trade turnover, export, import, China, European Union.

Якприклад впливу глобалізації на систему сучасних міжнародних відносиндержав в даній статтірозглянуті тенденціїрозвиткуміжнародних відносин між Китайською Народною Республікою таїголовними партнерами, які займають лідируючі позиції на політичній карті світу, надаючи сильний вплив на хід міжнародних подій і процесів в умовах глобальних змін. Одночасно цей процес зустрічає на своєму шляху труднощі і протиріччя. У cmammi висвітлено зовнішньоекономічні зв'язки Китаю з провідними країнами світу. Проаналізовано торгово-економічне та інвестиційне співробітництво Китаю з країнами ЄС. Актуальність дослідження обумовлена тим, що Китай і Європейський союз є провідними гравиями світової політики. Отже, вивчення зовнішньополітичного курсу КНР щодо ЄС має велику науково-практичну значимість. Тема дослідження обгрунтовується появою нових фракторів і умов, що впливають на розвиток китайсько-європейського економічного співробітництва i, в зв'язку з цим виявленням найбільш перспективних напрямків для такого співробітництва. В основі моделі міжнародних відносин Китаю лежить гармонізація зв'язків з країнами світу. Стрімко зростаюча роль Китаю в сфрері міжнародних відносин, підйом економіки як найважливіша передумова послідовного, стабільного розвитку країни відображає реальність заявленого Китаєм розгортання «періоду великих стратегічних можливостей», в якому провідною тенденцією китайської зовнішньої політики стає прагматизм, спрямований на забезпечення національних довгострокових иілей. Цілеспрямованість, динамізм, послідовність - так можна охарактеризувати китайську зовнішню політику. 3 точки зору загального балансу сил на світовій арені, численне, освічене населення Китаю, його величезні ринки, а також зростаюча роль в світовій економіці обіцяють світу нові можливості. Тому найбільш потужним фрактором подальшої глобалізації суспільства в найближчі десятиліття може стати необхідність об'єднання зусиль світової спільноти для боротьби з глобальними проблемами. Це головна умова встановлення надійного правопорядку, здатного підвищити ефективність управління глобальними процесами на міжнародному рівні.

Ключові слова: глобалізація, міжнародні відносини, міжнародна торгівля, зовнішньоторговельний оборот, експорт, імпорт, Китай, Європейський союз. 
В качестве примера влияния глобализации на систему современных международных отношений государств в данной статье рассмотрены тенденции развития международных отношений между Китайской Народной Республикой и её главными партнерами, которые занимают лидирующие позиции на политической карте мира, оказывая сильнейшее влияние на ход международных событий и процессов в условиях глобальных перемен. В статье освещены внешнеэкономические связи Китая с ведущими странами мира. Проанализировано торгово-экономическое и инвестиционное сотрудничество Китая со странами EC. Актуальность исследования обусловлена тем, что Китай и Европейский союз являются ведущими игроками мировой политики. Следовательно, изучение внешнеполитического курса КНР в отношении ЕС имеет большую научно-практическую значимость. Тема исследования обосновывается появлением новых фракторов и условий, влияющих на развитие китайско-европейского экономического сотрудничества и, в этой связи выявлением наиболее перспективных направлений для такого сотрудничества.

Ключевые слова: глобализация, международные отношения, международная торговля, внешнеторговый оборот, экспорт, импорт, Китай, Европейский союз.

Problem formation. The modern world is undergoing an era of global change. That is why it is important to study the impact of globalization on political relations and international relations. Globalization has posed a number of complex challenges to the world.

In conditions of interdependence, globalization is a comprehensive, complex phenomenon that affects almost all aspects of human life and makes important changes not only in the economic and political sphere but also in international relations and international trade.

In the context of financial and economic difficulties, there is a growing dependence of the member states of the European Union (hereinafter - the EU) on access to China's financial resources. The EU is confronted acutely with the problem of collective action, being an association of states with similar and different interests. At the same time, the mechanisms existing in the EU to overcome this problem do not always ensure the optimization of its course in cooperation with major partners. As an example of the impact of globalization on the system of modern international relations of states, this article considers the development of international relations by the People's Republic of China (hereinafter - the PRC).

Analysis of recent research and publications. Currently, the scientific community pays great attention to the study and analysis of global development trends. However, given the novelty of the phenomenon of integration at the global level, expert assessments are often opposite and contradictory. The phenomenon of globalization and its influence on the system of modern international relations have been studied by such scientists as I.A. Vasilenko [1], V.B. Kuvaldin, A.I. Utkin [5], T.V. Podolskaya [2], W. Beck, E. Giddens, J. Stiglitz [4], J. Soros, and others.

When writing the article, special attention in the study of the interaction of the parties was paid to statements by the leaders of the PRC and the EU, as well as a joint communiqué following the meeting. The article draws on a wide range of sources, the authors of which investigated the policy of China in relation to the European Union: German researcher N. Etzel, American expert D. Chambo, Italian researcher N. Casarini.

Task formation. The aim of the study is to analyse China's international relations with the European Union and the leading countries of the world.

Statement of the main material. Each country pays special attention to the development of its foreign trade, maintaining good neighbour relations with its key partners.
Today, China is a key global player and a leading technological force. Its growing presence in the world, including in Europe, should be accompanied by increased responsibility for maintaining order based on international rules, as well as greater reciprocity, non-discrimination, and openness of its system. Reform ambitions promulgated in China must be translated into policies or actions commensurate with its role and responsibility.

Currently, China's foreign trade is characterized by rapid growth and positive indicators: the labour productivity of foreign trade enterprises, the efficiency of the provision and the use of capital and resources are growing. Environmental protection is gradually coming to the fore in business processes. China has stepped up its activities in the field of innovation and green development. The assortment is also growing, the quality of products and services - both consumers and manufacturers are striving for high quality. Intellectual qualitative development of all sectors is observed.

The main export items of China remain the traditional labour-intensive high-tech categories of goods, products of the engineering and electrical industries. There is also an increase in imports of consumer goods, iron ore, crude oil and natural gas, both in quantitative and in value terms.

PRC is the main market for the global petrochemical industry while it demonstrates great potential for growth and development. Accelerating the development of foreign markets by Chinese enterprises through high-quality investment and construction will bring new opportunities to the world.

In terms of the scale of the petrochemical industry, China is one of the leading places in the world. Over the past 6 years, China's petrochemical industry has grown rapidly. In 2018, China's petrochemical industry continued to develop with a focus on structural and supply reforms, and actions to reduce excess and inefficient production capacities were strengthened.

A proactive and state-run industrial and economic policy in China, such as "Made in China 2025", aims to develop domestic leading companies and assist them in strategic high-tech sectors in the world.

The period of globalization marked the development trend of international organizations around the world, which reflects the growing interest of states to actively improve their international status by participating in multilateral forums and jointly solving problems for their effective settlement. The regional integration associa- 
tion in Southeast Asia, ASEAN, which is now steadily developing relations with China, a state that is gaining more and more momentum on the world stage, is not an exception.

The ASEAN + 3 format is successful from the point of view of the PRC-ASEAN cooperation itself because it is aimed both at deepening economic cooperation and at creating qualitatively new cooperation at the regional level between ASEAN and East Asia [6].

International relations are actively developing between China and the UN. China's increase in UN funding, the implementation of a number of joint projects to help the poorest countries, and China's increased participation in UN peacekeeping operations. China's desire is to uphold globalization and promote the idea of creating free trade zones, relying on the mechanism of multilateral diplomacy, especially the UN. The mentioned initiatives serve the national interests of China. They give it the opportunity to ensure the security of Chinese companies and citizens, protect strategic lines of communications in countries affected by the war, and contribute to improving the Chinese image in the international arena, thereby attracting an increasing number of states to the circle of its partners.

This may allow China to lead the efforts of a number of states in the future to stabilize the regions supplying important products for economic growth and the fight against neo-protectionism, which ultimately will be beneficial both for the UN, receiving funding from China for programs to achieve the Millennium Goals, and China itself, who will be able to more effectively develop the safe and peaceful international environment necessary for its peaceful rise [3].

China is the leader in terms of investments in "pure" energy in 2015, having increased the total investment by $17 \%$ to $\$ 110.5$ billion compared to the previous year. As of 2016, China's green economy index was 41.8, which is 64th in the world ranking. The government has spurred the development of environmental power plants in order to meet the demand for electricity and limit emissions from thermal power plants. China is increasingly focusing on the renewable energy industry. According to a study by the National Renewable Energy Center of China, the state can cover $85 \%$ of total electricity production and $60 \%$ of primary energy consumption from renewable energy sources by 2050.

As for the economic component of China's interests in Europe, it should be mentioned that at the end of November 2017, the last three countries from Central and Eastern Europe - Estonia, Lithuania, and Slovenia agreed to join the "One Belt One Road" Chinese
Economic Initiative. Thus, 16 countries of Central and Eastern Europe - Albania, Bulgaria, Bosnia and Herzegovina, Hungary, Latvia, Lithuania, Macedonia, Poland, Romania, Serbia, Slovakia, Slovenia, Croatia, Montenegro, Czech Republic, and Estonia joined the "New Economic Silk Road" and "Sea Silk Road of the XXI century" projects. This suggests that European countries are increasingly showing interest in China as a world economic leader. They are also interested in opening new markets for European goods and services in the Asia-Pacific region. It is planned that the main directions of the new silk road will be: China - Central Asia - Russia - Europe (to the Baltic Sea), China - Central and West Asia - the Persian Gulf and the Mediterranean Sea; China - Southeast Asia - South Asia - Indian Ocean. Europe is one of the goals and within the framework of the Sea Silk Road: South China Sea - Indian Ocean - Europe; another direction runs through the South China Sea to the Pacific. Thus, "One Belt One Road" will cover 60 countries of the world. China intends to invest in its partners, as well as fully and scale to enter the EU market.

In the last decade, Europe has grown an understanding that China's economic power and political influence are growing and continuing to grow at an unprecedented scale, reflecting China's desire to become a leading world power. As we see, there are serious prospects for the economic rapprochement of China and Europe.

China and the European Union have strong ties. They are two of the three largest economies and traders in the world. China is currently the EU's second-largest trading partner after the United States, and the EU is China's largest trading partner. Both sides are committed to a comprehensive strategic partnership, as expressed in the strategic cooperation program between China and the EU until 2020.

Thus, systematizing the exact data of trade turnover [7] between China and the EU for 2015-2018 in Table 1, we predict what the further development of trade will be until 2025 (taking into account the growth of indicators by $6 \%$ each year).

One can see that over the analysed period, indicators of import and export of China are growing. Despite the fact that in 2016, China's exports to the EU slightly decreased (by 8.09 billion euros than in 2015), with each year China's exports are 2 times higher than its imports.

Such a positive trade turnover is explained by the fact that Chinese economic strategies have an individual approach to each new market. There is not a single country in Europe that exports to China as much as the PRC brings to these countries.

Foreign trade turnover of PRC and the EU for 2015-2025

\begin{tabular}{|c|c|c|c|c|c|c|c|c|c|c|c|}
\hline & $\mathbf{2 0 1 5}$ & $\mathbf{2 0 1 6}$ & $\mathbf{2 0 1 7}$ & $\mathbf{2 0 1 8}$ & $\mathbf{2 0 1 9}$ & $\mathbf{2 0 2 0}$ & $\mathbf{2 0 2 1}$ & $\mathbf{2 0 2 2}$ & $\mathbf{2 0 2 3}$ & $\mathbf{2 0 2 4}$ & $\mathbf{2 0 2 5}$ \\
\hline $\begin{array}{c}\text { Total import-export, } \\
\text { billion euros }\end{array}$ & 549,87 & 550,45 & 615,32 & 623,34 & 660,74 & 700,38 & 742,41 & 786,95 & 834,17 & 884,22 & 937,27 \\
\hline $\begin{array}{c}\text { China imports from } \\
\text { the EU, billion euros }\end{array}$ & 168,63 & 177,3 & 207,5 & 210,55 & 223,18 & 236,57 & 250,77 & 265,81 & 281,76 & 298,67 & 316,59 \\
\hline $\begin{array}{c}\text { China exports to the } \\
\text { EU, billion euros }\end{array}$ & 381,24 & 373,15 & 407,82 & 412,79 & 437,56 & 463,81 & 491,64 & 521,14 & 552,41 & 585,55 & 620,68 \\
\hline Balance, billion euros & 212,61 & 195,85 & 200,32 & 202,24 & 214,37 & 227,24 & 240,87 & 255,32 & 270,64 & 286,88 & 304,09 \\
\hline
\end{tabular}




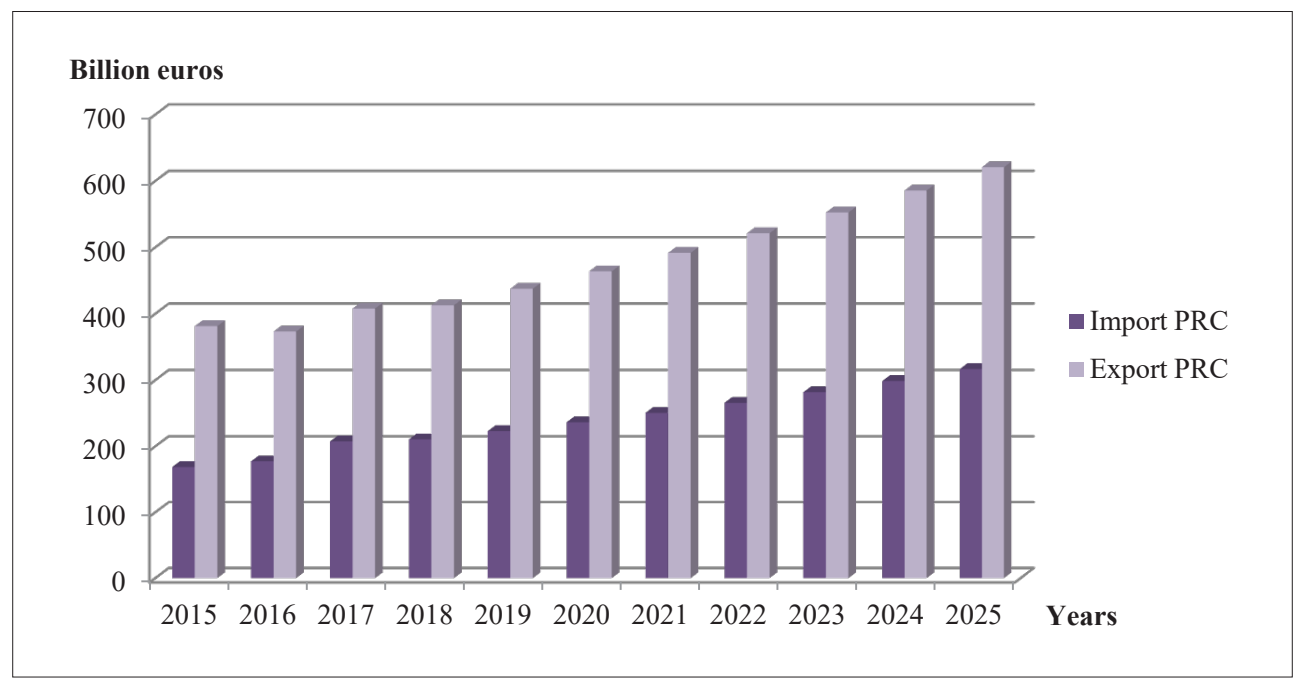

Fig.1. Foreign trade turnover of PRC and the EU for the period of 2015-2025

It is obvious that China's leadership in Europe will only grow every year, increasing its supplies to the EU. We observe a positive trade balance of China in trade with EU countries. This confirms the rapid economic growth of China.

According to the forecast until 2025, the foreign trade turnover of China and the EU will be more than 900 billion euros, based on the fact that China continues to expand the borders of trade relations with the EU countries.

For the first time in history, China has become Germany's largest foreign trade partner, which is one of the largest manufacturing countries and is faced with the real need to move from "manufacturing capabilities" to "smart manufacturing" using digital and new technologies. Therefore, Germany really hopes to strengthen cooperation with China.

Sino-German trade and economic cooperation is showing good dynamics. The volume of trade between China and Germany in 2018 reached \$ 183.9 billion, which is $9.4 \%$ more than in 2017 . For the 7 months of 2019, China's investment in the German economy amounted to $\$ 1.01$ billion, an increase of $27.6 \%$. German investment in China amounted to $\$ 1.17$ billion, an increase of $62.7 \%$. Consequently, for three consecutive years, China has been Germany's largest trading partner.

The second most important partner of China in Europe is the United Kingdom. In the future, this country intends to exceed the scale of trade and economic cooperation between Germany and Beijing. According to the forecasts of the former Chancellor of the Treasury, J. Osborne, by 2025, China will take a strong position after the United States as the country's second trading partner. So far, the British-Chinese trade is much more modest than German-Chinese and barely exceeds $\$ 76$ billion. At the same time, in 2000-2016, London has become the undisputed European leader in attracting foreign direct investment from China.

The financial hub connects the two countries. The importance of cooperation in finance is confirmed by the UK joining the Asian Infrastructure Investment Bank (AlIB). Also, at the end of 2018, the People's Bank of
China and the Bank of England extended a currency swap agreement, allowing the parties to conduct exchange transactions in the amount of 150 billion yuan to 40 billion pounds.

The UK intends to become China's best Western partner and, in general, help build relations between China and Europe. Britain urgently needs to update the infrastructure in the production of electricity, including nuclear energy, and in the field of railway communication. China has extensive expertise and tools to help. This is a great benefit for both countries. Regarding the Brexit process, nearly half of the 212 British companies opened in China believe that this could have a positive impact on the business if London and Beijing enter into a free trade agreement.

France is the third most important partner of the PRC among the EU member states. Paris perceives relations with Beijing, first, as a source of restoration of economic growth. In trade, there is also a positive trend. Leadership in the purchase of French assets of national importance again belongs to China. France agreed on cross-investment in industry, aviation, and nuclear energy. More than 1,600 French enterprises are already operating in China, while there are 700 branches of Chinese companies in France.

$5 G$ technology is the foundation of the digital economy and digital communities around the world. That is why the EU strongly supports all actions aimed at finding international consensus and developing cooperation in the $5 G$ sphere. By signing an agreement with China, the European Union has formed a powerful team with the participation of the most important Asian partners, which should make $5 \mathrm{G}$ a reality throughout the world by 2020 . This is an important step towards $5 \mathrm{G}$ success.

The outcome of the China-EU Summit on April 9, 2019, was the adoption of a joint declaration in which Beijing and Brussels were able to achieve most of their goals. In a declaration, the PRC and the EU agreed to reform the World Trade Organization (WTO) to address "global trade challenges". The communiqué says that to achieve this, both sides will intensify discussions to strengthen international rules on industrial subsidies. 
The parties also agreed to eliminate "discriminatory requirements and practices" in relation to foreign investors. To this end, China and the EU want to conclude a comprehensive investment agreement. The summit participants even agreed on a time frame: to reach an agreement before the end of the year and sign an agreement in 2020.

In addition, in 2019, China and the EU want to complete negotiations on an agreement on the protection of product name origin. The world's largest open procurement market is the EU market. At the same time, EU companies often face difficulties in gaining access to procurement opportunities in the Chinese market, as well as in other foreign markets, in particular in sectors where EU companies are highly competitive (e.g., transportation equipment, telecommunications, electricity generation, medical equipment and construction services). This protectionist trend is intensifying. Therefore, in order to promote reciprocity and open up procurement opportunities in China, the European Parliament and the Council should adopt the International Procurement Tool by the end of 2019 .

To consolidate the common interests of the Member States, China and the EU approved the ambitious "Strategic EU-PRC Cooperation Agenda 2020", which includes about 100 articles on a wide range of issues of economic interaction [8].

Summary. Having analysed international relations and international trade of the PRC, it should be summarized that China has achieved impressive results in recent years. The clearly impending restructuring of the global system of international relations is impossible without the participation of China.

China for a good right takes a place in the UN Security Council, is an active participant in all international initiatives aimed at solving complex global problems.

Having analysed the foreign trade turnover of the PRC and the EU, we can say that China is becoming a strategic competitor for the EU more and more, exports to EU countries exceeds imports by 2 times.

Therefore, we can conclude that the development of trade and economic relations between China and Europe has rather great prospects. Given the fact that European countries and China are mutually interested in the development of trade relations, the further development of projects such as the "New Economic Silk Road" and the "Sea Silk Road of the XXI Century", as well as the land Eurasia corridor, will positively affect the increase in turnover. In the future, the development of foreign economic relations can lead to an increase in mutual investment in various industries.

The success achieved by China in the field of international relations is largely the result of its significant economic achievements. But these achievements were achieved thanks to the active role of Chinese foreign policy, Chinese diplomacy, which continues to act skilfully in the current conditions, making efforts to the economic growth of the country and to turn the PRC into a powerful, prosperous, highly developed modern state, enjoying influence in the world.
Thus, the defining trend in the development of international relations, despite all the crises, failures and retreats, is the convergence of countries and peoples in a single global space.

\section{Бібліографрічний список:}

1. Василенко И.А. Глобализация мировой экономики: за ред. Бревдо Т.В. Москва, 2008.

2. Подольская Т.В. Глобализация и транснационализация мировой экономики в геоэкономическом пространстве: брошюра. Ростов-на-Дону : СКАГС, 2008. 48 с.

3. Колодий Р. Сотрудничество ООН и Китая: новейшие тенденции и перспективы. Шевченковская весна: материалы международной научно-практической конференции студентов, аспирантов и молодых учених, Киев : Киевский национальный университет им. Тараса Шевченко, Институт международных отношений, 2017. C.

4. Стиглиц Дж. Ю. Глобализация: тревожные тенденции / пер. с англ. Г.Г. Пирогова. Москва : Национальный общественно-научный фонд, 2003. 304 с.

5. Уткин А.И. Векторы глобальных перемен: анализ и оценки основных факторов мирового политического развития. Полис. Политические исследования. 2000. № 1.

6. Haacke J. Seeking influence: China's diplomacy toward Asean after the Asian crisis / Lynne Rienner Publishers, 2002. C. $13-52$.

7. Where does China export and import from? : веб-сайт URL: https://oec.world/en/visualize/tree_map/hs07/import/ chn/show/all/2017/ (дата звернення: 7.10.2019).

8. EU-China 2020 Strategic Agenda for Cooperation. European Union External Action. URL: http://eeas.europa.eu/archives/ docs/china/docs/eu-china_2020_strategic_agenda_en.pdf (дата звернення: 7.10.2019).

\section{References:}

1. Vasilenko I.A. (2008) Globalizacija mirovoj jekonomiki [Globalization of the world economy]. Moscow. (in Russian)

2. Podol'skaja T.V. (2008) Globalizacija i transnacionalizacija mirovoj jekonomiki v geojekonomicheskom prostranstve [Globalization and transnationalization of the global economy in the geoeconomic space]. Rostov-on-Don: SKAGS. p. 48 (in Russian)

3. Kolodij R. (2017) Sotrudnichestvo OON i Kitaja: novejshie tendencii i perspektivy [UN-China Cooperation: Recent Trends and Prospects]. Proceedings of the Shevchenkovskaja vesna: materialy mezhdunarodnoj nauchno-prakticheskoj konferencii studentov, aspirantov i molodyh uchenyh (Ukraine, Kiev,March 30, 2017), Kyiv: Kievskij nacionalnyj universitet im. Tarasa Shevchenko, Institut mezhdunarodnyh otnoshenij, pp. 43-47.

4. Stiglic Dzh. Ju. (2003) Globalizacija: trevozhnye tendencii [Globalization: Alarming Trends]. Moscow: Nacionalnyj obshhestvenno-nauchnyj fond, p. 304. (in Russian)

5. Utkin A.I. (2000) Vektory globalnyh peremen: analiz i ocenki osnovnyh faktorov mirovogo politicheskogo razvitija [Vectors of global change: analysis and assessment of the main factors of world political development] Policy. Policy research, vol № 1.

6. Haacke J. (2002) Seeking influence: China's diplomacy toward Asean after the Asian crisis, Lynne Rienner, pp.13-52.

7. Where does China export and import from?: Available at: https://oec.world/en/visualize/tree_map/hs07/import/chn/ show/all/2017/ (accessed 7 October 2019)

8. EU-China 2020 Strategic Agenda for Cooperation. European Union External Action. Available at: http://eeas.europa.eu/ archives/docs/china/docs/eu-china_2020_strategic_agenda_en.pdf (accessed 7 October 2019) 